\title{
The evolution of mitochondrial DNA in Partula
}

\author{
JAMES MURRAY,* O. COLIN STINE* $\ddagger \&$ MICHAEL S. JOHNSON $\dagger$ \\ *Department of Biology, University of Virginia, Charlottesville, VA 22901, USA and tDepartment of Zoology, University \\ of Western Australia, Nedlands, Western Australia 6009, Australia
}

\begin{abstract}
The mitochondrial DNA of species of land snails of the genus Partula from the Society Islands has been analysed by means of restriction enzymes to determine relationships within the genus. Seventeen variable restriction sites were mapped onto the $14.5 \mathrm{~kb}$ mtDNA. These sites are highly variable within species. In $P$. suturalis, those genotypes occurring within a population are usually separated by single-step changes, and the differences between populations are geographically coherent. There is no detectable association between the distribution of mitochondrial genotypes and the occurrence of dextral or sinistral populations, confirming that chirality does not constitute a genetic barrier in this species. P. taeniata also shows a coherent geographic pattern of genotype distribution within and between populations. The mitochondrial differences between morphologically similar populations in the northeast and northwest suggest that the similarity may be the result of convergence. Despite the regular patterns of distribution within species, some genotypes are widely shared among species. One pattern was found in four species on Moorea and two species on the neighbouring island of Tahiti. Shared genotypes may represent ancestral forms or they may have resulted from hybridization. However we believe that the most attractive hypothesis is that they are subject to selection. Studies of Partula demonstrate that the evolution of the morphological, electrophoretic, and mitochondrial phenotypes occur at variable rates, independently of one another.
\end{abstract}

Keywords: mitochondrial DNA, Patula, population structure, restriction mapping, speciation.

\section{Introduction}

The land snails of the genus Partula provide unusually favourable material for the study of variation in natural populations. The genus contains about a hundred species distributed over the high (volcanic) islands of the South Pacific with the greatest diversity in the Society Islands of French Polynesia (Crampton, 1916, 1932). Each island in the Societies harbours a closely related group of species as we have shown by means of breeding studies, multivariate morphometric analysis, and protein electrophoresis (Murray \& Clarke, 1968, 1976a, b, 1980; Clarke \& Murray, 1969; Johnson et al., 1977, 1986a, b). On the island of Moorea, for example, there are seven species. Two of these are the terminal members of a ring species, and two other pairs of species hybridize in some localities (Murray \& Clarke, 1980). Within species there is extensive variation. Crampton (1932) recognized six morphological subspecies in Partula taeniata and two in $P$. suturalis. In addition, some populations of $P$. suturalis are dextral, some are sinistral, and some are polymorphic for chirality.

The electrophoretic analysis of enzyme variation supports the hypothesis that all the species from any one island form a monophyletic group, with the species from each successively younger island derived from those on the next older adjacent island (Johnson, Murray \& Clarke, 1986a).

This conclusion conflicts with the widely accepted model of geographic speciation by multiple invasions in archipelagoes. This model predicts that morphologically similar species from different islands, such as $P$. taeniata from Moorea and $P$. filosa from Tahiti should be genetically more closely related than the morphologically and reproductively distinct $P$. taeniata and $P$. suturalis from Moorea.

In an effort to determine more exactly the relationships within the genus we have examined the restriction genotypes of the mitochondrial DNA of the species inhibiting the two youngest of the Society Islands, Moorea and Tahiti. By means of radiometric dating, these islands have been shown to have maximum ages of 1.5 and 1.0 million years respectively (Duncan \& McDougall, 1976). 
Analysing restriction sites in mitochondrial DNA has proved to be useful for assessing the relationships between closely related species and between populations within species (Brown \& Wright, 1979; Ferris et al., 1983; Lansman et al., 1983; Mulligan \& Chapman, 1989; for reviews, see Avise, 1986; Avise et al., 1987; Moritz et al., 1987). The small size, high copy number, extra-nuclear location, and maternal inheritance combine to make mtDNA especially favourable material with which to measure genetic relatedness.

Some organisms, however, have raised special problems in the isolation of mtDNA. Molluscs are among the most difficult, and we have needed to devise particular methods for dealing with land snails (Stine, 1989). From these animals we are now able to make reliable preparations for analysis with restriction endonucleases.

In this study we have analysed the fragments generated with restriction enzymes to construct maps of the mtDNA of snails from 22 Moorean populations, including all seven species on the island, and from seven populations representing six of the Tahitian species. Two populations of an additional species from the island of Huahine have been included for comparison. These data provide new insights into the evolution of mtDNA and illuminate the relationships among the species of Partula and among the various kinds of characters used in phylogenetic studies.

\section{Materials and methods}

The stocks for this study were collected in the wild in 1980,1982 , or 1984. Each population (with one exception, $P$. mirabilis $)$ is represented by a sample collected from an area of $10 \times 10 \mathrm{~m}$ or less. Some of the specimens were freshly killed animals from the holding and breeding colony at the University of Virginia. Others were animals that had been killed by freezing at $-80^{\circ} \mathrm{C}$. We could not detect any difference between preparations from fresh and frozen specimens.

The isolation of the mitochondrial DNA of land snails has proved to be very difficult, but special methods for controlling nucleases and removing mucopolysaccharides devised by one of us (Stine, 1989) have made it possible to accomplish this goal. The foot, genitalia, and hepato-pancreas of individual snails were minced and then homogenized in $2 \mathrm{ml}$ of ice-cold $0.25 \mathrm{~m}$ sucrose in TEK ( $50 \mathrm{~mm}$ Tris- $\mathrm{HCl}, \mathrm{pH} 7.5,10$ mM EDTA, 1.5 per cent $\mathrm{KCl}$ ) containing $140 \mu \mathrm{g} / \mathrm{ml}$ of ethidium bromide (to inhibit nuclease activity) in a Dounce homogenizer. Mucopolysaccharides were removed by centrifuging the sample through a layer of $1.1 \mathrm{~m}$ sucrose in TEK at $13,0000 \mathrm{~g}$ for $45 \mathrm{~min}$ at $4^{\circ}$. The pellet was resuspended and again centrifuged through the dense sucrose.

The mitochondria were disrupted by resuspension in ice-cold TEK containing 2 per cent NP40, lysing all membranes except for the nuclear membranes. The nuclei and tissue debris were pelleted by centrifugation. The supernatant was then extracted with phenol and chloroform, and the DNA recovered by ethanol precipitation.

Restriction digests were prepared with Bam HI, Hind III, Pst I, and Xho I. The yields of mtDNA from individual animals were small because of the small body size $(<0.5$ gram wet weight before dissection) and the extra steps necessary to isolate DNA from molluscs (see above and in Stine, 1989). Thus only three to seven digests per sample, depending on the size of the snail, could be prepared. The restriction fragments were separated by electrophoresis on agarose gels and transferred by Southern blotting to Gene

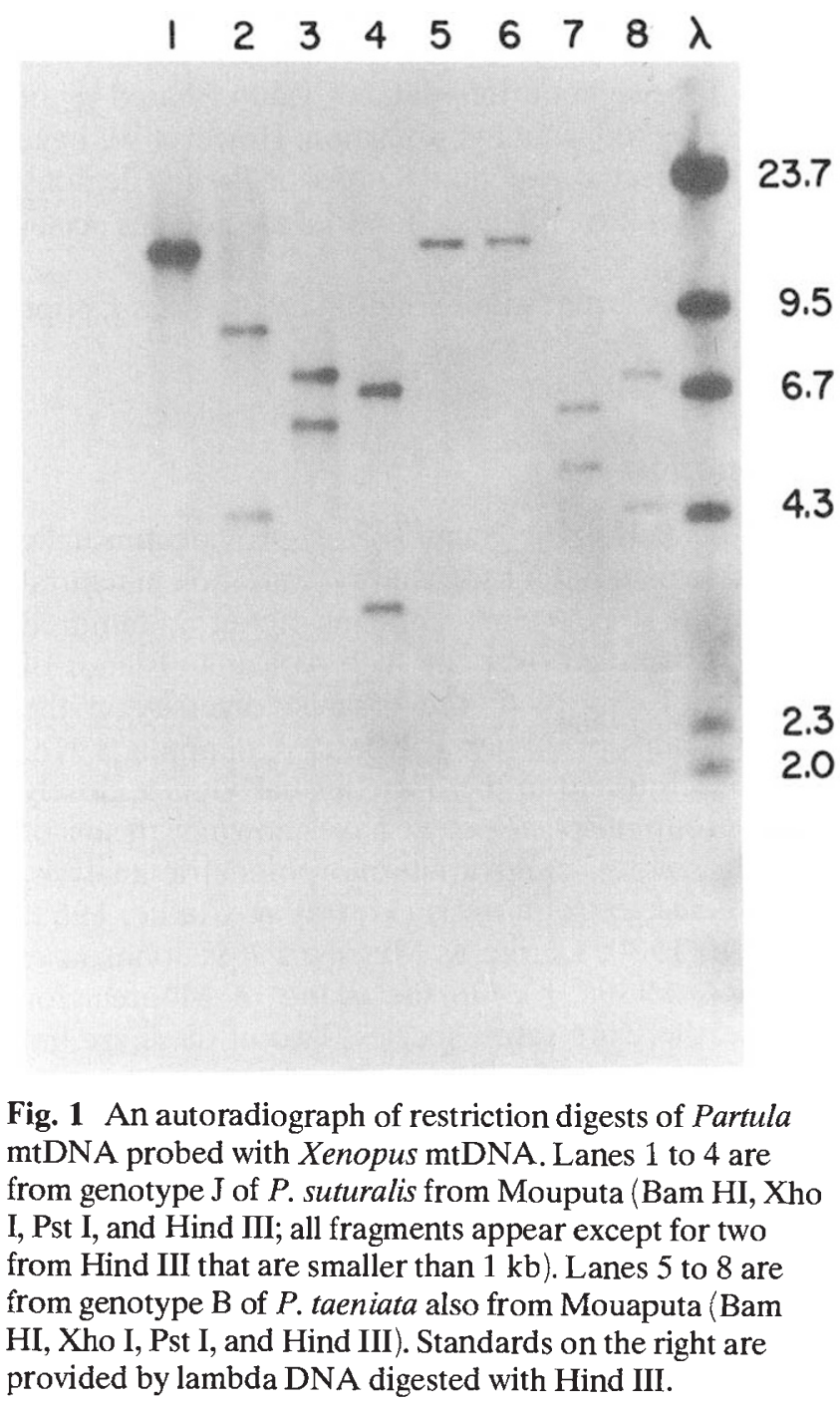


Screen Plus (New England Nuclear). The blots were probed with radioactively labelled mtDNA from the plasmid pXlm31, which contains the entire mitochondrial genome of Xenopus laevis (isolated by Igor Dawid). This probe successfully hybridizes with snail mtDNA at low stringency (see Fig. 1), since approximately 70 per cent of the sequence of many mitochondrial genes is shared by organisms from several different phyla (Howley et al., 1979; Clary \& Wolstenholme, 1985; Stine, 1989).

By using the restriction enzymes either singly or in pairs, it was possible to map the Partula mtDNA completely, thereby ensuring that the entire genome of the mitochondrion is accounted for. The resulting maps were analysed by treating the restriction sites as individual characters that were either present or absent in any particular genotypic map. PAUP (Swofford,
1985) was employed to search for the most parsimonious phylogenetic relationships among the genotypes represented in the populations in this study.

\section{Results}

We were able to isolate mitochondrial DNA and map the restriction sites from 227 snails in 31 populations of 14 species of Partula. The localities are listed in Table 1, and those on Moorea and Tahiti are shown on the maps in Figs 2 and 3.

The lengths of fragments in single and double digests established that the mtDNA was approximately 14.5 kilobases in size. Thus the length is similar to the size of the mtDNA of Ascaris suum (14,284 base pairs, Wolstenholme et al., 1987). It contained 17 restriction sites for the four enzymes for which we have the most

Table 1 Localities in the Society Islands from which individuals were drawn for analysis of mitochondrial DNA

\begin{tabular}{|c|c|c|c|c|c|}
\hline Island & Valley & $\begin{array}{l}\text { Sample } \\
\text { no. }\end{array}$ & $\begin{array}{l}\text { Sample } \\
\text { size }\end{array}$ & Species & $\begin{array}{l}\text { Genotypes } \\
\text { found }\end{array}$ \\
\hline Moorea & Mouaputa & M639 & 5 & $P$. taeniata & A, B \\
\hline Moorea & Atimaha & 26.2 & 6 & P. taeniata & A \\
\hline Moorea & Maramu & M750 & 5 & $P$. taeniata & C, D \\
\hline Moorea & Faatoai & 25.1 & 17 & $P$. taeniata & $\mathrm{E}, \mathrm{F}, \mathrm{G}$ \\
\hline Moorea & Faamaariri & 24.3 & 6 & $P$. taeniata & $\mathrm{H}$ \\
\hline Moorea & Paparoa & 20.1 & 6 & P. exigua & I \\
\hline Moorea & Mouaputa & M639 & 34 & $P$. suturalis & $\mathrm{A}, \mathrm{J}$ \\
\hline Moorea & Maharepa & 21.1 & 3 & P. suturalis & $\mathrm{A}, \mathrm{J}$ \\
\hline Moorea & Fanautaata & 18.2 & 3 & P. suturalis & $\mathbf{J}$ \\
\hline Moorea & Paahonu & M766 & 4 & $P$. suturalis & $\mathrm{K}, \mathrm{L}, \mathrm{M}$ \\
\hline Moorea & Atimaha & M832 & 7 & P. suturalis & $\mathrm{N}, \mathrm{O}$ \\
\hline Moorea & Vairahi & M699 & 6 & P. suturalis & $\mathrm{P}, \mathrm{Q}$ \\
\hline Moorea & Urufara & M647 & 17 & P. suturalis & $R, S$ \\
\hline Moorea & Haapiti & 23.4 & 3 & P. suturalis & $\mathrm{T}, \mathrm{U}$ \\
\hline Moorea & Tepatu & 16.1 & 3 & P. 'dendroica' & $\mathrm{J}$ \\
\hline Moorea & Fareaito & 27.2 & 4 & $P$. tohiveana & A \\
\hline Moorea & Mouaputa & M639 & 5 & P. 'olympia' & $\mathrm{A}, \mathrm{V}$ \\
\hline Moorea & Fanautaata & 18.3 & 3 & P. mooreana & $A, W$ \\
\hline Moorea & Maatea & M682 & 6 & P. mooreana & $\mathrm{A}$ \\
\hline Moorea & Vaianai & M679 & 4 & P. mooreana & A \\
\hline Moorea & Fareito & M692 \& 3 & 7 & P. mirabilis & $\mathbf{P}$ \\
\hline Moorea & Paparoa & 20.7 & 4 & $P$. aurantia & $\mathbf{R}$ \\
\hline Tahiti & Tiarei & $\mathrm{T} 811$ & 7 & P. otaheitana & $\mathrm{P}$ \\
\hline Tahiti & Tipaerui & T 859 & 9 & P. otaheitana & $\mathrm{X}, \mathrm{Y}$ \\
\hline Tahiti & Tiarei & $\mathrm{T} 811$ & 6 & P. affinis & $\mathrm{P}$ \\
\hline Tahiti & Faone & $\mathrm{T} 855$ & 3 & P. jackieburchi & $\mathrm{P}$ \\
\hline Tahiti & Papehue & $\mathrm{T} 801$ & 4 & P. nodosa & A, Z \\
\hline Tahiti & Pirae & $\mathrm{T} 858$ & 13 & P. filosa & $\mathrm{AA}, \mathrm{BB}, \mathrm{CC}, \mathrm{DD}$ \\
\hline Tahiti & Tiarei & T776 & 6 & $P$. hyalina & A \\
\hline Huahine & Turi, north & H589 & 9 & $P$. varia & $\mathrm{E}$ \\
\hline Huahine & Fitii & H586 & 12 & P. varia & FF \\
\hline
\end{tabular}




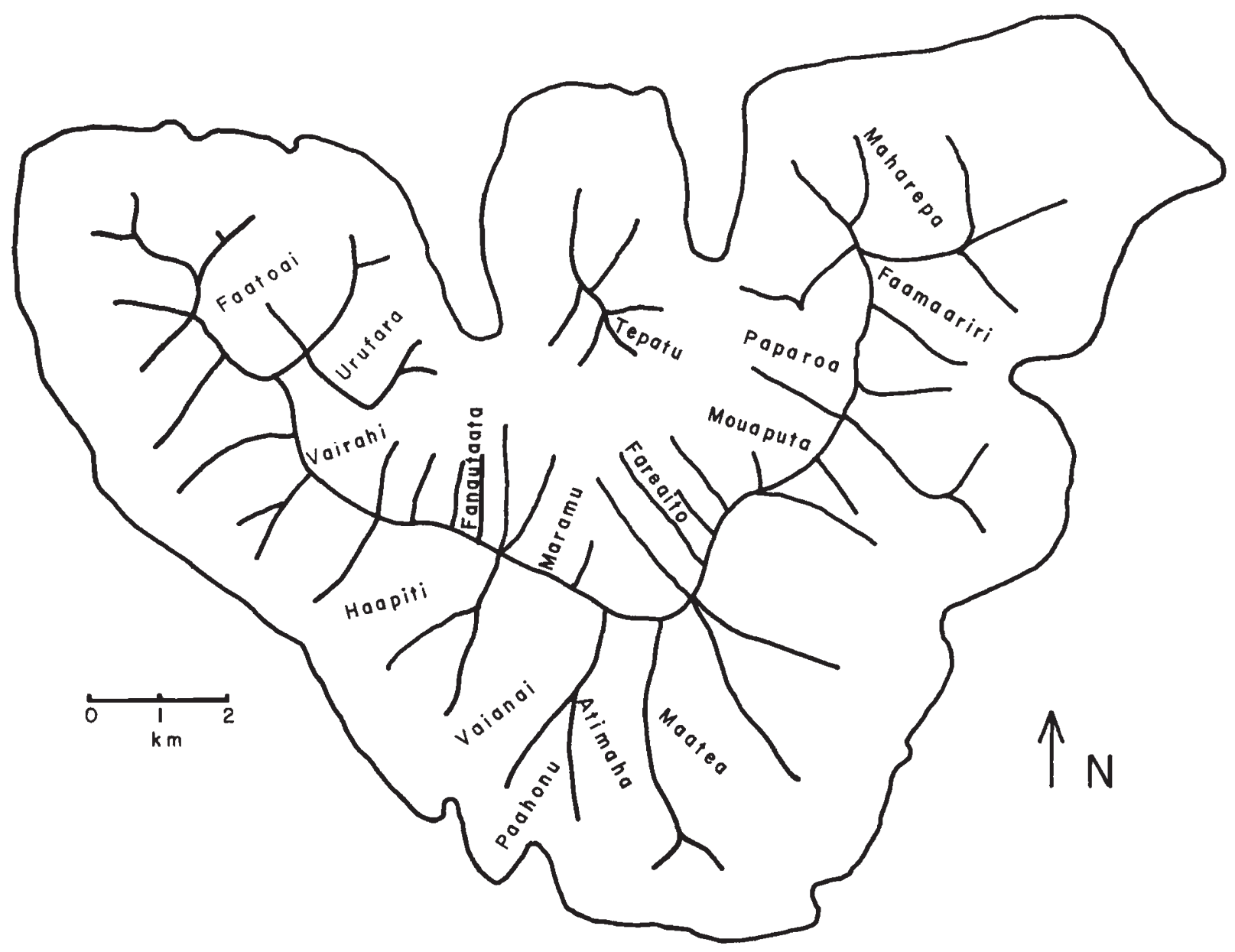

Fig. 2 The island of Moorea, Society Islands, showing valleys from which collections were taken. The interior lines indicate ridges.

complete data. In principle, 14 sites were phylogenetically informative, being present in at least two populations and absent from at least two others. Three sites were unique to single populations. The composite map of all the sites is shown in Fig. 4.

There is an unusual breadth of variation within the species of this genus. The distribution of the 32 observed mitochondrial genotypes is shown in Table 1 , and their combinations of restriction sites are recorded in Table 2. Twelve populations were polymorphic, containing at least two different genotypes. Of these, two populations had three different genotypes, and one had four.

The relationships among the populations of Partula suturalis, the most extensively sampled species in the study, are summarized in Fig. 5. The nine populations contained 13 different genotypes, with two additional hypothetical ones being required to connect those actually observed. Seven of the populations were shown to be polymorphic, one containing three different genotypes. Despite the substantial variation within and between populations, two of the genotypes (A and $\mathrm{J}$ ) were quite widely distributed, occurring in both sinistral and dextral populations of $P$. suturalis. One of these $(\mathrm{J})$ was also found in the Tepatu population, which was formerly assigned to $P$. dendroica (Crampton, 1932), but which has been shown to be conspecific with $P$. suturalis (Murray \& Clarke, 1980). The populations with the $\mathrm{A}$ and $\mathrm{J}$ genotypes are clustered together in the northeast and central valleys. There are two groups of highly variable populations, those in the south near Mt. Ahutau (K, L, M, N and O) and those in the west (P, Q, R, S, T and U). The similarities among genotypes within each of these geographic groups are higher than those between the groups, providing further evidence of geographic coherence of the variation.

The relationships among populations of Partula 
Fig. 3 The island of Tahiti, Society Islands, showing valleys from which collections were taken. The interior lines indicate ridges.
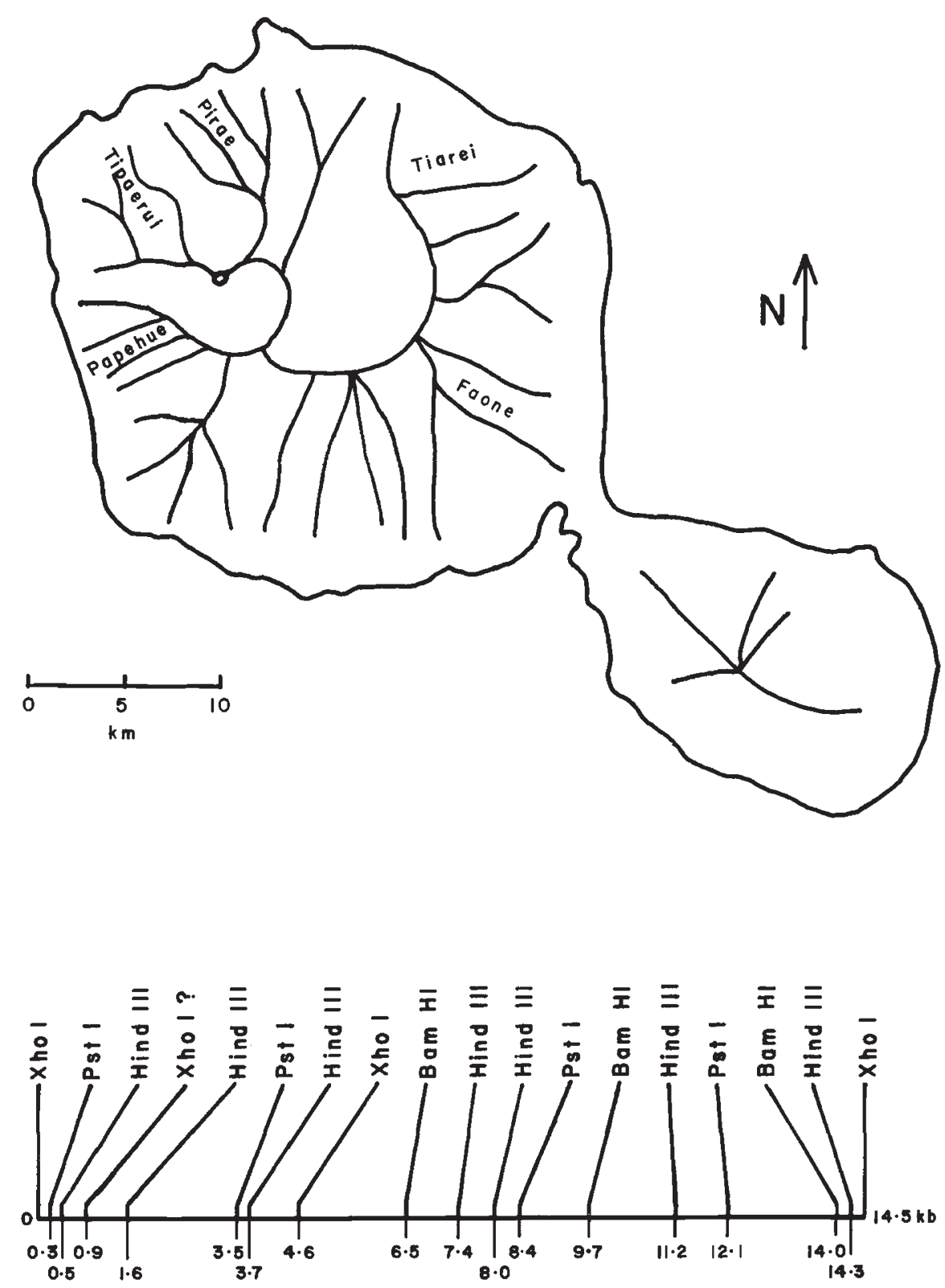

Fig. 4 A map of restriction sites detected in the mtDNA of Partula species. The site labelled Xho I? has not been definitively located; it is either at 0.9 (as shown) or at 3.7 on the map. taeniata and the closely related $P$. exigua are shown in Fig. 6 . Three of the six populations are polymorphic with 10 genotypes overall, three of them from a single population. Again there is a coherent geographical pattern, but it differs from that in $P$. suturalis in at least two respects. First, the southern population shares a genotype with one of the central populations. Second, it is the populations in the northeast, both $P$. taeniata $(\mathrm{H})$ and the closely related $P$. exigua $(\mathrm{I})$ that show large differences from each other and from the rest of the populations of $P$. taeniata.
The 32 genotypes found among the 14 species demonstrate that the mtDNA of Partula has undergone extensive changes during the evolution of the genus. Nevertheless some genotypes are shared quite widely within the genus. The most common (A) is found in $P$. suturalis, $P$. taeniata, $P$. tohiveana, and $P$. mooreana on Moorea and in $P$. nodosa and $P$. hyalina on Tahiti. A second genotype $(\mathrm{P})$ is shared by three species on Tahiti and two on Moorea. These two genotypes are separated by two steps. We have not found the intermediate; but it is interesting that this pattern would 
Table 2 Genotypes detected among populations of Partula from the Society Islands. Restriction sites are ordered as in Fig. $4.1=$ presence of site; $0=$ absence; $9=$ uncertainty (some animals have the site, some do not; but its association with other sites is uncertain)

\begin{tabular}{|c|c|c|c|c|c|c|c|c|c|c|c|c|c|c|c|c|c|}
\hline & \multicolumn{17}{|c|}{ Restriction sites } \\
\hline & $\mathrm{X}$ & $P$ & $\mathrm{H}$ & $\mathrm{X}$ & $\mathrm{H}$ & $\mathbf{P}$ & $\mathrm{H}$ & $\mathrm{X}$ & B & $\mathrm{H}$ & $\mathrm{H}$ & $\mathrm{P}$ & $\mathrm{B}$ & $\mathrm{H}$ & $P$ & B & $\mathrm{H}$ \\
\hline A & 1 & 1 & 1 & 0 & 1 & 0 & 1 & 1 & 0 & 0 & 1 & 1 & 0 & 0 & 0 & 1 & 0 \\
\hline B & 1 & 1 & 1 & 0 & 1 & 1 & 1 & 1 & 0 & 0 & 1 & 1 & 0 & 0 & 0 & 1 & 0 \\
\hline C & 0 & 1 & 1 & 0 & 9 & 0 & 1 & 1 & 0 & 0 & 1 & 1 & 0 & 0 & 0 & 1 & 0 \\
\hline D & 0 & 1 & 1 & 0 & 9 & 1 & 1 & 1 & 0 & 0 & 1 & 1 & 0 & 0 & 0 & 1 & 0 \\
\hline $\mathrm{E}$ & 0 & 1 & 1 & 0 & 1 & 0 & 1 & 1 & 0 & 0 & 1 & 1 & 0 & 0 & 0 & 0 & 0 \\
\hline $\mathrm{F}$ & 0 & 1 & 1 & 0 & 1 & 0 & 0 & 1 & 0 & 0 & 1 & 1 & 0 & 0 & 0 & 0 & 0 \\
\hline G & 1 & 1 & 1 & 0 & 1 & 0 & 0 & 1 & 0 & 0 & 1 & 1 & 0 & 0 & 0 & 0 & 0 \\
\hline $\mathrm{H}$ & 0 & 0 & 1 & 0 & 1 & 1 & 1 & 0 & 0 & 0 & 1 & 1 & 0 & 0 & 0 & 0 & 0 \\
\hline I & 1 & 0 & 1 & 0 & 1 & 1 & 1 & 0 & 0 & 0 & 1 & 1 & 0 & 0 & 1 & 1 & 0 \\
\hline $\mathrm{J}$ & 1 & 1 & 1 & 0 & 1 & 0 & 1 & 1 & 0 & 1 & 1 & 1 & 0 & 0 & U & 1 & 0 \\
\hline K & 1 & 1 & 1 & 0 & 1 & 0 & 1 & 1 & 0 & 9 & 0 & 1 & 0 & 0 & 0 & 1 & 0 \\
\hline $\mathrm{L}$ & 1 & 1 & 1 & 0 & 1 & 0 & 1 & 0 & 9 & 1 & 0 & 1 & 0 & 0 & 0 & 1 & 0 \\
\hline M & 1 & 1 & 1 & 0 & 1 & 0 & 1 & 0 & 1 & 0 & 0 & 1 & 0 & 0 & 0 & 1 & 0 \\
\hline $\mathrm{N}$ & 1 & 0 & 1 & 0 & 1 & 1 & 1 & 0 & 1 & 0 & 0 & 1 & 0 & 0 & 0 & 1 & 0 \\
\hline $\mathrm{O}$ & 1 & 0 & 0 & 0 & 1 & 1 & 1 & 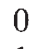 & 1 & 0 & 0 & 1 & 0 & 0 & U & 1 & 0 \\
\hline $\mathrm{P}$ & 1 & 0 & 1 & 0 & 1 & 0 & 0 & 1 & 0 & 0 & 1 & 1 & 0 & 0 & U & 1 & 0 \\
\hline Q & 1 & 0 & 1 & 0 & 1 & 0 & 0 & 1 & 0 & 0 & 0 & 1 & 0 & 0 & 0 & 1 & 0 \\
\hline $\mathrm{R}$ & 1 & 0 & 1 & 0 & 1 & 0 & 0 & 1 & 0 & 1 & 0 & 1 & 0 & 0 & 0 & 1 & 0 \\
\hline$S$ & 1 & 0 & 1 & 0 & 1 & 0 & 0 & 1 & 0 & 1 & 0 & 0 & 0 & 0 & 0 & 1 & 0 \\
\hline $\mathrm{T}$ & 1 & 0 & 0 & 0 & 1 & 0 & 0 & 1 & 0 & 0 & 1 & 1 & 0 & 0 & 0 & 1 & 0 \\
\hline $\mathrm{U}$ & 0 & 0 & 1 & 0 & 1 & 0 & 0 & 1 & 0 & 0 & 1 & 1 & 0 & 0 & 0 & 1 & 0 \\
\hline V & 1 & 1 & 1 & 0 & 1 & 0 & 1 & 1 & 0 & 0 & 1 & 1 & 0 & 0 & 1 & 1 & 0 \\
\hline W & 1 & 1 & 0 & 0 & 0 & 0 & 1 & 0 & 0 & 0 & 1 & 1 & 0 & 0 & 0 & 1 & 0 \\
\hline$X$ & 1 & 0 & 1 & 0 & 1 & 0 & 0 & 0 & 0 & 1 & 0 & 1 & 0 & 0 & 0 & 1 & 0 \\
\hline $\mathrm{Y}$ & 1 & 0 & 1 & 0 & 1 & 0 & 0 & 0 & 0 & 1 & 0 & 1 & 0 & 0 & 1 & 1 & 0 \\
\hline Z & 1 & 0 & 1 & 0 & 1 & 0 & 1 & 0 & 0 & 1 & 1 & 1 & 0 & 0 & 0 & 1 & 0 \\
\hline $\mathrm{AA}$ & 1 & 0 & 0 & 0 & 1 & 0 & 1 & 1 & 0 & 1 & 1 & 1 & 0 & 0 & 1 & 1 & 1 \\
\hline BB & 1 & 0 & 0 & 1 & 1 & 0 & 1 & 1 & 0 & 1 & 1 & 1 & 0 & 0 & 1 & 1 & 1 \\
\hline $\mathrm{CC}$ & 1 & 0 & 0 & 1 & 1 & 0 & 1 & 1 & 0 & 1 & 1 & 0 & 0 & 0 & 1 & 1 & 1 \\
\hline DD & 1 & 0 & 0 & 1 & 1 & 0 & 1 & 1 & 0 & 1 & 1 & 0 & 0 & 1 & 1 & 1 & 1 \\
\hline $\mathrm{EE}$ & 9 & 0 & 1 & 0 & 1 & 0 & 0 & 0 & 1 & 0 & 0 & 9 & 9 & 1 & 0 & 1 & 0 \\
\hline FF & 9 & 0 & 1 & 0 & 1 & 0 & 1 & 0 & 1 & 0 & 1 & 9 & 9 & 0 & 0 & 1 & 0 \\
\hline
\end{tabular}

constitute a consensus sequence, since it would contain the most common state of each of the restriction sites over all the patterns.

We have used PAUP (Swofford, 1985) to search for the most parsimonious phylogenetic tree embracing the variation in Table 2 . The minimum tree that we have found requires 43 steps, but there are many equally parsimonious trees that differ in detail. The principal problem is that changes at different sites are not very consistent with one another (consistency index $=0.37$ ), implying that much of the change has not been progressively divergent. Only three restriction sites are completely consistent with the minimum trees, and two of these occur in the highly differentiated branch of $P$. filosa. Thus there must have been a considerable amount of reversal, parallelism, and/or convergence during the evolution of the group. Under these circumstances the relationships are best expressed as a network that allows us to show multiple similarities. Figure 7 embraces all single- and doublestep changes together with those of higher order that represent minimum connections.

In spite of the uncertainties stemming from this inconsistency, clear systematic and geographic relationships are shown by the data at three levels. First, different genotypes found within the same population of a species tend to differ from one another by changes at single sites. In $P$. filosa, for example, there are four 
Fig. 5 A map of Moorea showing the geographical locations from which the various mitochondrial genotypes of $P$. suturalis were collected. Each change in a restriction site between genotypes is indicated by a crossbar. Genotypes within the same population are shown by contiguous squares. They are related by single-step changes with the exception of $\mathrm{T}$ and $\mathrm{U}$, and also $\mathrm{K}$, and $\mathrm{M}$.

In each of these cases one two-step change is required.

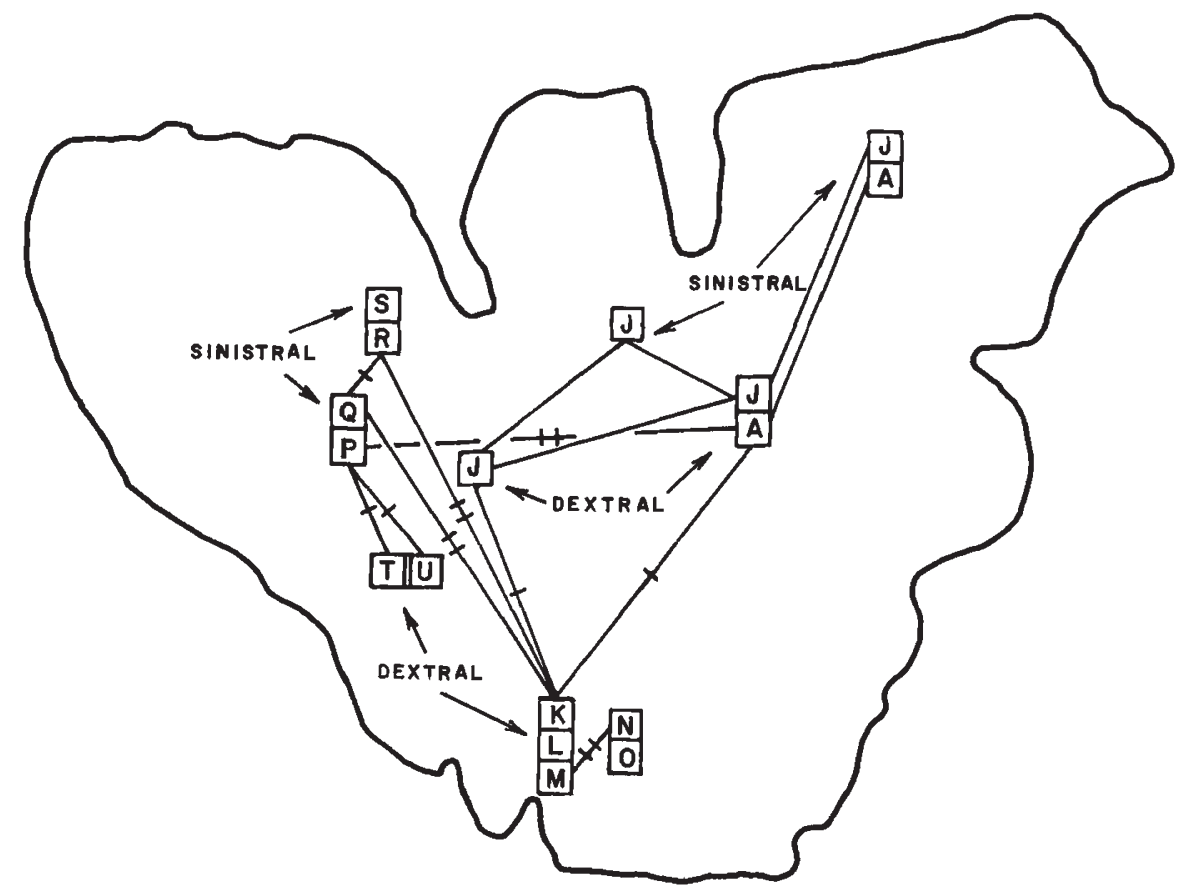

Fig. 6 A map of Moorea showing the geographical locations from which the various genotypes of $P$. taeniata and the closely related $P$. exigua were collected. Triangles $=P$. taeniata ; circle $=$

P. exigua. Conventions are as in Fig. 5.

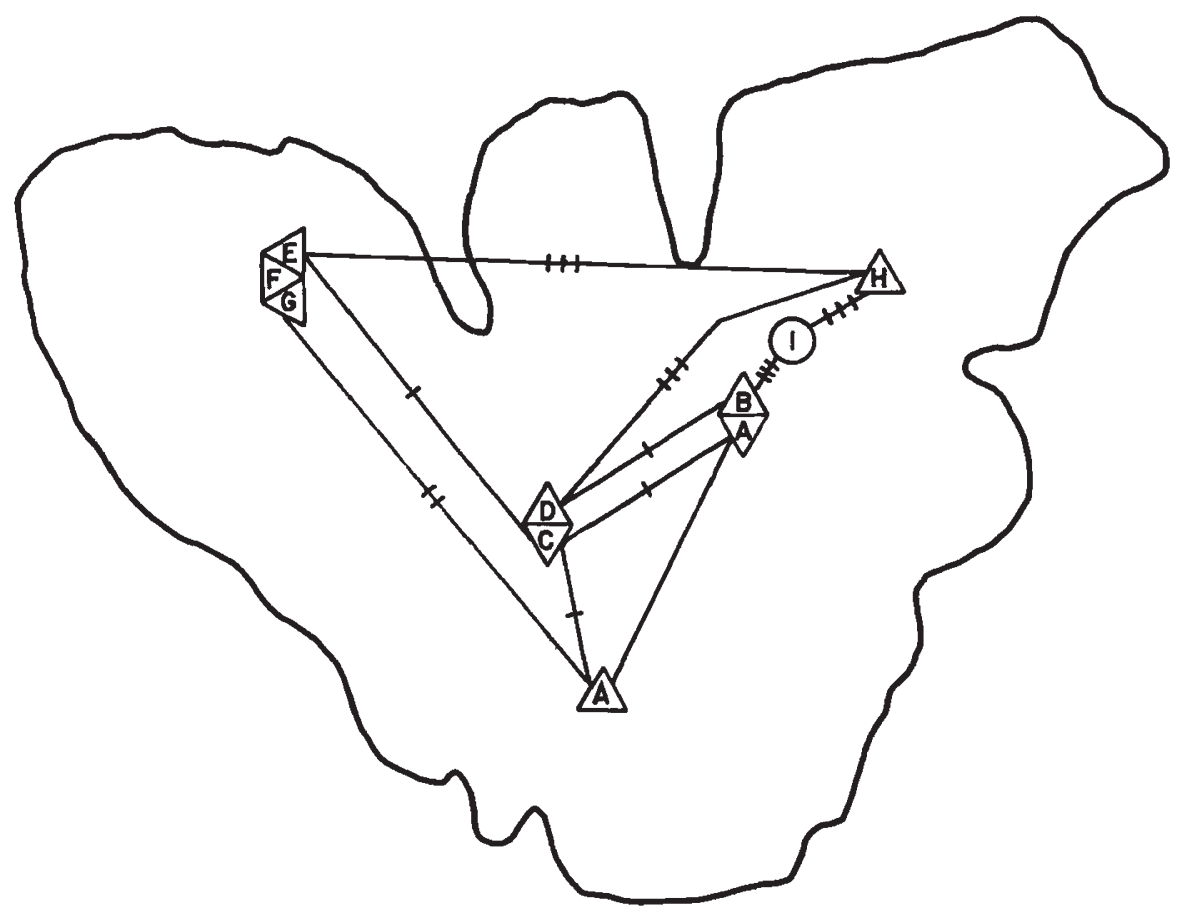

genotypes separated by three single-step changes; and in $P$. taeniata from Faatoai there are three genotypes separated by two single-step changes. There are four exceptions to this generalization: two-site differences separate genotypes found in $P$. suturalis from Paahonu and from Haapiti; three-site differences, in $P$. mooreana from Fanautaata and in $P$. nodosa. However the sample sizes from these populations are small, and the intermediates may have been missed.

Second, genotypes tend to be closely related to their closest geographical neighbours. This pattern extends beyond the relationships already noted for $P$. suturalis 


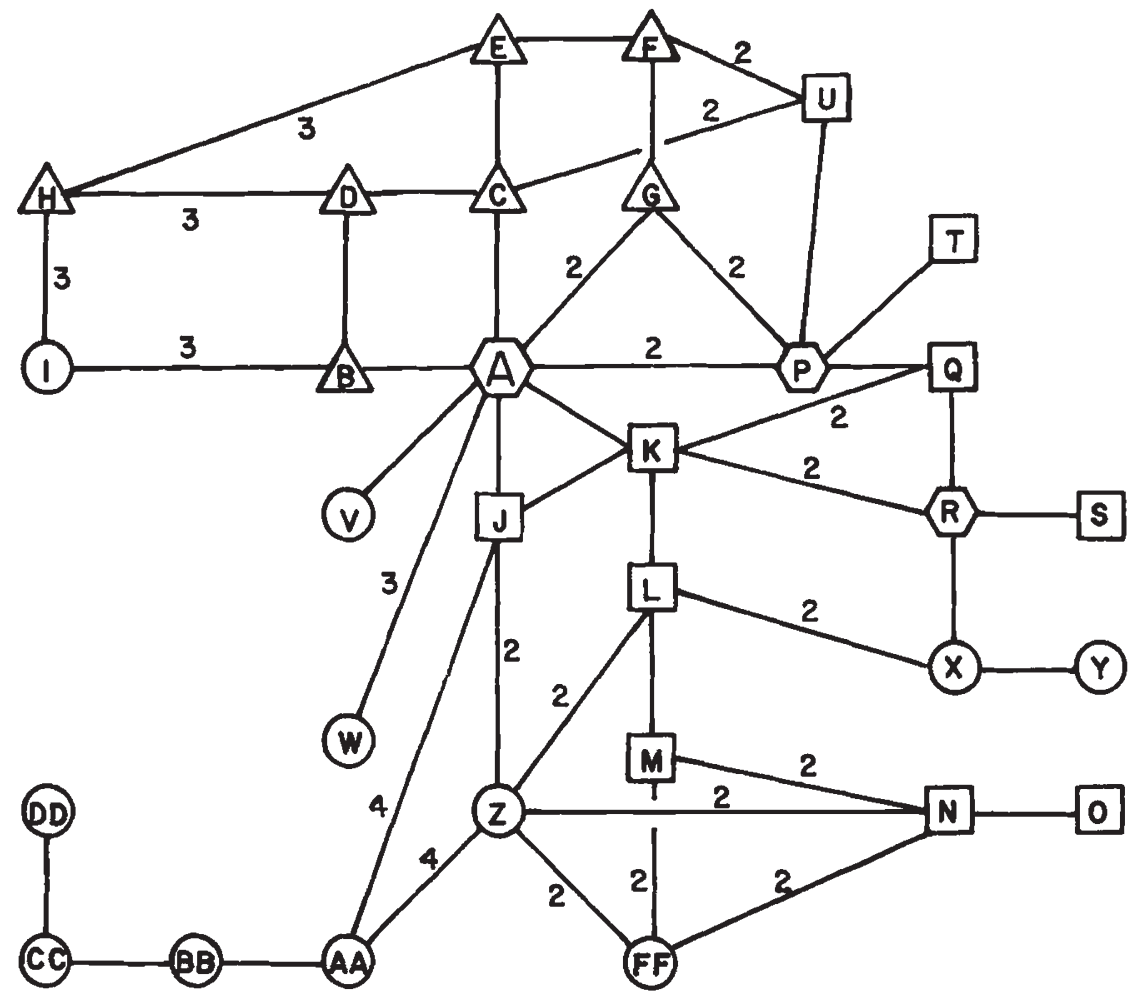

Fig. 7 A network showing the relationships of the genotypes found in this study. Squares $=P$. suturalis alone; triangles $=P$. taeniata alone; circles $=$ other species alone; hexagons $=$ genotypes shared by more than one species. All single and twostep relationships are given, together with greater differences when these are the closest relationships. There are a few omissions for the sake of clarity. $\mathrm{EE}$ is related by three steps each to FF, $\mathrm{M}, \mathrm{N}, \mathrm{Q}$, and $\mathrm{X}$. I is also related to N, V, $\mathrm{Z}$, and FF by three; and $\mathrm{AA}$, to $\mathrm{T}$ and $\mathrm{V}$ by four steps. and $P$. taeniata. There is a close geographical association of the two suturalis populations containing the widely shared genotype $\mathrm{A}$ with the other species in which this genotype occurs, at least on Moorea. This genotype is found in two populations of $P$. tohiveana

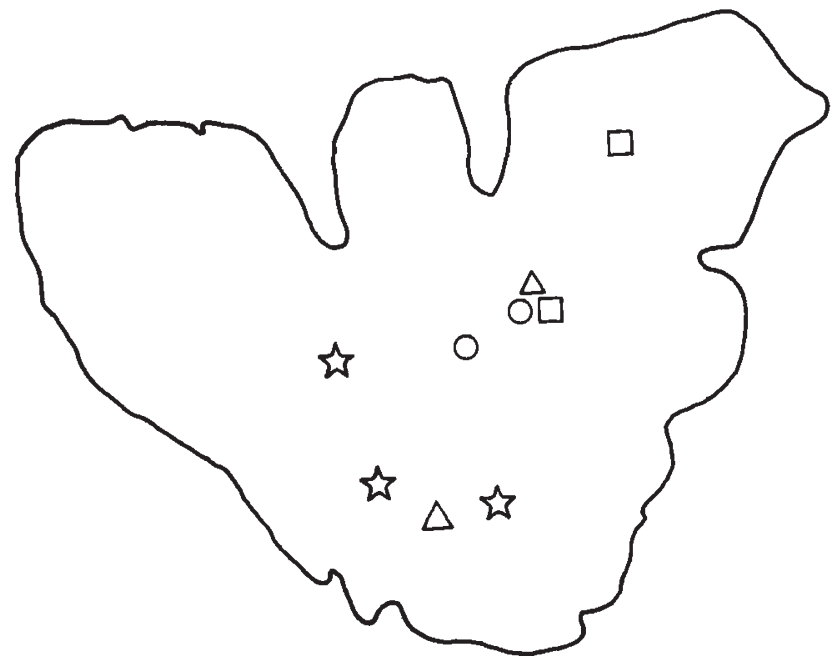

Fig. 8 Populations in which the shared genotype A has been found. Squares $=P$. suturalis; triangles $=P$. taeniata; circles $=P$. tohiveana $($ including $P$. 'olympia'); stars $=P$. mooreana. Not shown are $P$. nodosa and $P$. hyalina from Tahiti. (including $P$.'olympia'), three of $P$. mooreana, and two of $P$. taeniata from the northeast to the centre and south of the island (see Fig. 8). The association is curious in the light of the occurrence of this genotype in two species on Tahiti.

The second widely shared genotype $(\mathrm{P})$ is found in $P$. otaheitana, $P$. affinis, and $P$. jackieburchi from Tahiti and in $P$. suturalis and $P$. mirabilis from Moorea. Two of the Tahitian species come from the same locality. There is some question about the status of the three Tahitian taxa. Crampton (1932) considered affinis to be a 'sympatric sub-species' of otaheitana. Kondo (1980) originally described jackieburchi, on account of the structure of the genitalia, as a member of the related genus Samoana. However the evidence from the electrophoretic analysis of enzyme polymorphisms suggests that all three of these taxa are very closely related (Johnson et al., 1986c), but we do not yet know whether they exchange genes.

\section{Discussion}

The results of our study of the mtDNA in Partula present us with patterns of variation that are quite familiar in some respects and very surprising in others. Although the extent of the variation within individual species is large for species with such restricted distribu- 
tions, the geographic coherence of the variation is what we have come to expect from other studies of this sort (Avise, 1986). Genotypes within the same population tend to differ from one another by single-step changes, and neighbouring populations are more similar to one another than are those from further away.

However, when we compare the patterns of mitochondrial relationships among species with those derived from the study of morphological and electrophoretic characters, something quite different emerges. No two character sets provide congruent estimates of the phylogeny of the group. Our first consideration, therefore, must be whether or not the new data are reliable.

Two lines of reasoning strongly support the reliability of these data. First, the ability to map each restriction site on mtDNA of a uniform size rules out the possibility that our results stem either from loss of fragments or from mistaken similarities. Under these circumstances the use of a heterologous probe for the detection of restriction fragments appears to be entirely justified. Although it has been shown that evolutionary changes involving about 30 per cent of the mitochondrial genome occur very rapidly (Brown et al., 1979), the remaining 70 per cent, containing the genes encoding the large and small subunits of ribosomal RNA, the three cytochrome oxidase subunits, cytochrome $b$, and subunit 8 of the ATPase, are sufficiently similar across phyla to permit hybridization of mtDNA at low stringency (Clary \& Wolstenholme, 1985; Howley et al., 1979). In particular, the Xenopus probe has been shown to be effective in detecting restriction fragments from molluscan mtDNA (Stine, 1989).

Second, the rates of change required to produce the observed degree of differentiation in Partula are not excessively high. Following Nei \& Li (1979) the minimum average similarity among the mtDNA genotypes of Partula on Moorea and Tahiti is 0.6, corresponding to a sequence divergence of 0.0426 . Since the total time allowed by the geological age of the islands is 1.5 million years, the estimated rate of sequence divergence is 2.8 per cent/MY, very close to the 2 per cent/ MY estimated for primates (Brown et al., 1982).

Nor is it unusual to find mtDNA genotypes widespread within a species. Such genotypes have been observed, for example, in Homo sapiens (Johnson et al., 1983) and Agelaius phoeniceus (Ball et al., 1988). What is remarkable about the Partula results is the extent to which the common genotypes are distributed across species boundaries.

The shared genotypes and their meaning. The most common genotypes in our survey tend to be shared among more than one species. For example, pattern A has been found on Moorea in two populations of $P$. suturalis, two of $P$. tohiveana (including one originally described by Crampton as $P$. olympia), three of $P$. mooreana, and two of $P$. taeniata. It also occurs on Tahiti in populations of $P$. nodosa and $P$. hyalina. These include species that are very different in their morphology, their ecology, their breeding biology, and their genetics as assayed by the electrophoresis of enzymes (Murray \& Clarke, 1980; Johnson et al., 1986b). There are at least three hypotheses that might explain this extraordinary similarity.

The first is that this identity represents the retention of an ancestral genotype in the several species. This explanation is attractive because of the central position of the shared genotypes in the minimum-length network (Fig. 7). Neigel and Avise (1986) have modelled the process of mitochondrial sorting in lineages derived from populations with more than one type of mtDNA. With reasonable assumptions they have shown that two species may retain shared ancestral mitochondrial genotypes for approximately $4 \mathrm{~N}$ generations. It is conceivable, therefore, that some of the genotypes shared by closely related species of Partula may be explained simply by delay in the sorting out of ancestral genotypes. However, the process of sorting in recently separated lineages can hardly account for the common genotypes in all the species, especially those occurring on Tahiti and Moorea, such as $P$. nodosa and $P$. hyalina, which differ substantially from the Moorean species in their allozymes (Johnson et al., 1986a).

Murray \& Clarke (1984) have estimated the approximate generation time in Partula to be three years and the effective population sizes to be between 400 and 2000 individuals. These statistics would establish an upper limit for the time of separation of the six species sharing the A genotype of about 24,000 years. Such a short time is quite incompatible with estimates of the evolution of enzyme polymorphism in these species. Using the maximum time allowed by the geological ages of the islands it has been shown that the change in Nei's D (Nei, 1978) has been at least twice as large as one might expect from other studies (Johnson et al., 1986a; Maxson \& Maxson, 1979). Accepting the recent separation of the Partula species would require rates of enzyme evolution about 100 times faster than 'normal'.

An additional argument against the sorting hypothesis is that if $\mathrm{N}$ is small, then diversity within populations should be low. Our observations show that even with relatively small sample sizes, multiple genotypes are common within populations from localities no larger than $10 \times 10 \mathrm{~m}$.

The second hypothesis is that the genotypes have 
been shared through hybridization. It has been suggested that this process is responsible for similarity of mtDNA is closely related species (Ferris et al., 1983). A number of Partula species have been shown to be able to exchange genes. P. suturalis and tohiveana are the terminal members of a circular overlap which includes the intermediate from $P$. 'olympia' (Murray \& Clarke, 1980). Individuals from all three of these taxa share the A genotype. Other pairs of species known to hybridize are $P$. suturalis and aurantia, $P$. taeniata and exigua, and $P$. taeniata and mirabilis. Thus there are abundant opportunities for mitochondria to cross species boundaries. On the other hand, $P$. suturalis, $P$. taeniata, and $P$. mooreana, which share the A genotype, have been shown to be reproductively quite distinct (Murray \& Clarke, 1980). These observations and the occurrence of shared genotypes in species from both Moorea and Tahiti argue against the hypothesis of hybridization.

A final hypothesis, as suggested by Whittam et al. (1986) for Homo sapiens, is that selection favours the common genotype or genotypes (see also Adams \& Rothman, 1982; Aquadro et al., 1984). The two widely shared genotypes ( $\mathrm{A}$ and $\mathrm{P}$ ) differ by changes at only two positions. The missing intermediate could be considered a consensus genotype since its sequence would contain the most common state of each restriction site scored over all the observed patterns. Moreover, the analysis has shown that convergence is a prominent feature of the evolution of these sites. Taken together, the wide divergence, the conservative retentions, and the evidence of reversal argue that the common genotypes are ones that have been modified and reconstituted more than once. We therefore suggest that the common genotypes probably present selectively favoured stable states, with individual sites departing from and returning to the norm.

Mitochondrial phylogeny. Taking into consideration the evidence for reversal and convergence, any phylogenetic analysis must be approached with caution. There are a number of trees, differing in their details, that have the same number of steps. The most conservative approach to phylogenetic analysis in this case is therefore to base our conclusions on a network of relationships rather than on a conventional tree. The network in Fig. 7 clearly shows the reasons for this choice.

The network has, of course, no root. We originally included the species $P$. varia from the Leeward Island of Huahine in the expectation, based on allozyme analysis (Johnson et al., 1986a), that it would provide a useful outgroup. However, $P$. varia is extremely polymorphic, and we were therefore unable to establish individual maps unequivocally. Thus its point of con- nection to the tree is uncertain. Another possible candidate for the root would be the consensus genotype, which lies between the two widespread genotypes $A$ and $P$.

Within this framework some of the phylogenetic relationships are clear. The connection of $P$. taeniata to the rest of the species is almost certainly through the A genotype. The minimal network for the group (see Figs 6 and 7) provides an interesting comparison with the morphological relations of populations within the species. In $P$. taeniata there is a cline in shape from long, thin shells (ssp. elongata) in the south to short, fat shells (ssp. nucleola and strigata) in the north (Crampton, 1932). According to the mitochondrial relationships, the northeastern $(\mathrm{H})$ and northwestern subspecies $(E-F-G)$ represent separate branches of the tree. If this represents the true relationships within the species, then the similarity of the short, fat shells is convergent.

For $P$. suturalis the network shows clearly that neither the dextral nor the sinistral populations can be monophyletic. The sinistral populations in the northeast $(\mathrm{J}-\mathrm{A})$ and northwest $(\mathrm{R}-\mathrm{S})$ are more similar to adjacent dextral populations than they are to each other (see Figs 5 and 7). Moreover the dextral population in Haapiti $(\mathrm{T}=\mathrm{U})$ is more similar to the sinistral populations of the northwest than to the other populations of dextrals. This lack of congruence between the coils and the mtDNA confirms the independence of chirality and the other genetic characteristics of the population (Johnson, 1987; Johnson et al., 1987).

$m t D N A$ and allozymes. An additional instructive comparison is that between the degree of differentiation in two different classes of biochemical characters. The analysis of allozymes (Johnson et al., 1986b) shows extreme divergence in the populations of both $P$. taeniata and $P$. suturalis from the far south of Moorea. Indeed each is more different from other conspecific populations than those populations are from some other species in the genus. Either the southern populations were isolated before further speciation occurred in the group or else rates of change in these enzymes are not uniform. The data from mtDNA allow us to answer that question, since the results from the two species are very different. In $P$. taeniata the southern populations are the most conservative, showing the $A$ genotype whch links this species to the other members of the genus. On the other hand, the mtDNA from $P$. suturalis in this same area is very different from that of other populations of the species. We cannot say whether the genotypes found there are ancestral or derived, since that distinction depends heavily on how the network is rooted, but it is quite clear that isolation 
alone cannot explain the observed results in both $P$. taeniata and $P$. suturalis. We conclude therefore that the data from allozymes and from mtDNA can only be reconciled by accepting the hypothesis of variability in the rates of evolution of these biochemical characters.

The information that we have obtained on variation of the mtDNA in Partula reinforces our view that the species in this genus form a very closely related group. The substantial intraspecific genetic variation in this character set is consistent with the results from the genetics of colour patterns (Murray \& Clarke, 1976a, b), morphology (Murray \& Clarke, 1980), and protein electrophoresis (Johnson et al., 1986b). However, the different character sets evolve independently and at variable rates. This mosaic pattern of evolution can only occur if natural selection plays a role in the genetic differentiation of Partula.

\section{Acknowledgements}

We gratefully acknowledge the support of the US National Science Foundation (BRS 83-15097) and the Australian Research Grants Scheme. For the field work we were made welcome by Professor Bernard Salvat, Dr René Galzin, and the Centre de l'Environnement, Ile de Moorea, Antenne de Muséum National d'Histoire Naturelle. We thank Mr Stanley Mason for his careful work in the lab, and Professor Bryan Clarke, Dr Kirkby D. Smith, and Dr Graham Wallis for their helpful comments on earlier drafts of the paper. This paper is dedicated to our long-time friends and supporters of the Partula work, Mr and Mrs Medford Kellum of Opunohu, Moorea.

\section{References}

ADAMS, J. AND ROTHMAN, E. D. 1982. Estimation of phylogenetic relationships from DNA restriction patterns and selection of endonuclease cleavage sites. Proc. Natl Acad. Sci. USA, 79, 3560-3564.

AQUADRO, C. F, KAPLAN, N. AND RISKo, K. J. 1984. An analysis of the dynamics of mammalian mitochondrial DNA sequence evolution. Mol. Biol. Evol., 3, 423-434.

AVISE, J. C. 1986. Mitochondrial DNA and the evolutionary genetics of higher animals. Phil. trans. Roy. Soc., Lond. B, 312, 325-342.

AVISE, J. C., ARNOLD, J. BALL, R. M., BERMINGHAM, E. LAMB, T., NEIGEL, J. E., REEB, C. A. AND SAUNDERS, N. C. 1987. Intraspecific phylogeography: The mitochondrial DNA bridge between population genetics and systematics. Ann. Rev. Ecol. Syst., 18, 489-522.

BALL, R. M., FREEMAN, S., JAMES, F. C., BERMINGHAM, E. AND AVISE, J. C. 1988. Phylogeographic population structure of RedWinged Blackbirds assessed by mitochondrial DNA. Proc. Natl Acad. Sci. USA, 85, 1558-1562.
BROWN, W. M., GEORGE, M. AND WILSON, A. C. 1979. Rapid evolution of mitochondrial DNA. Proc. Natl Acad. Sci. USA, 76, 1967-1971.

BROWN, W. M., PRAGER, E. M., WANG, A. AND WILSON, A. C. 1982. Mitochondrial DNA sequences in primates: Tempo and mode of evolution. J. Mol. Evol., 18, 225-239.

BROWN, W. M. AND WRight, J. w. 1979. Mitochondrial DNA analyses and the origin and relative age of parthenogenetic lizards (genus Cnemidophorus). Science, 203, 1247-1249.

CLARKE, B. AND MURRAY, J. 1969. Ecological genetics and speciation in land snails of the genus Partula. Biol. J. Linn. Soc., 1, 31-42.

CLARY, D. O. AND WOLSTENHOLME, D. R. 1985. The mitochondrial DNA molecule of Drosophila yakuba: Nucleotide sequence, gene organization, and genetic code. J. Mol. Evol., 22, 252-271.

CRAMPTON, H. E. 1916. Studies on the variation, distribution, and evolution of the genus Partula. The species inhibiting Tahiti. Carnegie Institution of Washington, Publication No. 228, 1-311.

CRAMPTON, H. E. 1932. Studies of the variation, distribution, and evolution of the genus Partula. The species inhabiting Moorea. Carnegie Institution of Washington, Publication No. 410, 1-335.

DUNCAN, R. A. AND McDougALL, I. 1976. Linear volcanism in French Polynesia. J. Volcan. Geotherm. Res., 1, 197-227.

FERRIS, S. D., SAGE, R. D., HUANG, C. M., NIELSEN, J. T., RITTE, U. AND WILSON, A. C. 1983. Flow of mitochondrial DNA across a species boundary. Proc. Natl Acad. Sci. USA, 80, 2290-2294.

HOWLEY, P. M., ISRAEL, M. A., LAW, M. F. AND MARTIN, M. A. 1979. A rapid method for detecting and mapping homology between heterologous DNAs. J. Biol. Chem., 254, 4876-4883.

JOHNSON, M. J., WALLACE, D. C., FERRIS, S. D., RATTAZZI, M. C. AND CAVALLI-SFORZA, L. L. 1983. Radiation of human mitochondrial DNA types analysed by restriction endonuclease cleavage patterns. J. Mol. Evol., 19, 255-271.

Johnson, M. S. 1987. Adaptation and the rules of form: Chirality and shape in Partula suturalis. Evolution, 41, 672-675.

JOHNSON, M. S., CLARKE, B. AND MURRAY, J. 1977. Genetic variation and reproductive isolation in Partula. Evolution, 31, 116-126.

JoHNSON, M. S., MURRAY, J. AND CLARKE, B. 1986a. An electrophoretic analysis of phylogeny and evolutionary rates in the genus Partula from the Society Islands. Proc. Roy. Soc., Lond., B, 227, 161-177.

JOHNSON, M. S., MURRAY, J. AND CLARKE, B. 1986b. Allozymic similarities among species of Partula on Moorea. Heredity, 56, 319-327.

JOHNSON, M. S., MURRAY, J. AND ClARKE, B. $1986 \mathrm{c}$. High genetic similarities and low heterozygosities in land snails of the genus Samoana from the Society Islands. Malacologia, 27, 97-106.

JOHNSON, M. S., MURRAY, J. AND CLARKE, B. 1987. Independence of genetic subdivision and variation for coil in Partula suturalis. Heredity, 58, 307-313. 
KONDO, Y. 1980. Samoana jackieburchi, new species (Gastropoda: Pulmonata: Partulidae). Malacological Review, 13, 25-32.

LANSMAN, R. A., AVISE, J. C., AQUADRO, C. F., SHAPIRA, J. F. AND DANIEL, S. W. 1983. Extensive genetic variation in mitochondrial DNAs among geographic populations of the deer mouse Peromyscus maniculatus. Evolution, 37, 1-16.

MAXSON, L. R. AND MAXSON, R. D. 1979. Comparative albumin and biochemical evolution in plethodontid salamanders. Evolution, 33, 1057-1062.

MORITZ, C., DOWLING, T. E. AND BRowN, w. M. 1987. Evolution of animal mitochondrial DNA: Relevance for population biology and systematics. Ann. Rev. Ecol. Syst., 18, 269-292.

MULLIGAN, T. J. AND CHAPMAN, R. w. 1989. Mitochondrial DNA analysis of Chesapeake Bay white perch, Morone americana. Copeia, 1984, 679-688.

MURRAY, J. AND CLARKE, B. 1968. Inheritance of shell size in Partula. Heredity, 23, 189-198.

MURRAY, J. AND CLARKE, B. 1976a. Supergenes in polymorphic land snails. I. Partula taeniata. Heredity, 37, 253-269.

MURRAY J. AND CLARKE, B. 1976b. Supergenes in polymorphic land snails. II. Partula suturalis. Heredity, 37, 271-282.

MURRAY J. AND CLARKE, B. 1980. The genus Partula on Moorea: Speciation in progress. Proc. Roy. Soc. Lond., B, 211, 83-117.
MURRAY, J. AND CLARKE, B. 1984. Movement and gene flow in Partula taeniata. Malacologia, 25, 343-348.

$\mathrm{NEl}$, M. 1978. Estimation of average heterozygosity and genetic distance from a small number of individuals. Genetics, 89, 583-590.

NEI, M. AND LI, W.-H. 1979. Mathematical model for studying genetic variation in terms of restriction endonucleases. Proc. Natl Acad. Sci. USA , 76, 5269-5273.

NEIGEL, J. E. AND AVISE, J. C. 1986. Phylogenetic relationships of mitochondrial DNA under various demographic models of speciation. In Nevo, E. and Karlin, S. (eds) Evolutionary Processes and Theory, Academic Press, New York, pp. 515-534.

STINE, O. C. 1989. Cepaea nemoralis from Lexington, Virginia: The isolation and characterization of their mitochondrial DNA, the implications for their origin and climatic selection. Malacologia, 30, 305-315.

SWOFFord, D. L. 1985. Phylogenetic Analysis Using Parsimony. Illinois Natural History Survey, Champaign, IL.

WHITTAM, T. S., CLARK, A. G., STONEKING, M., CANN, R. L. AND WILSON, A. C. 1986. Allelic variation in human mitochondrial genes based on patterns of restriction site polymorphism. Proc. Natl Acad. Sci. USA, 83, 9611-9615.

WOLSTENHOLME, D. R., MACFARLANE, J. L., OKIMOTO, R., ClARY, D. O AND WAHLEITHNER, J. A. 1987. Bizarre tRNAs inferred from DNA sequences of mitochondrial genomes of nematode worms. Proc. Natl Acad. Sci. USA, 84, 1324-1328. 